\title{
The impact of metformin use on survival in prostate cancer: a systematic review and meta-analysis
}

\author{
Yao Xiao ${ }^{1, *}$, Lei Zheng ${ }^{2, *}$, Zubing $\mathrm{Mei}^{3}$, Changbao $\mathrm{Xu}^{1}{ }^{1}$, Changwei Liu ${ }^{1}$, Xiaohan Chu ${ }^{1}$ \\ and Bin Hao ${ }^{1}$ \\ ${ }^{1}$ Department of Urology, The Second Affiliated Hospital of Zhengzhou University, Zhengzhou, Henan Province, China \\ ${ }^{2}$ Department of Endocrinology, The First Affiliated Hospital of Chinese PLA General Hospital, Beijing, China \\ ${ }^{3}$ Department of Anorectal Surgery, Shuguang Hospital, Shanghai University of Traditional Chinese Medicine, Shanghai, China \\ *These authors contributed equally to this work \\ Correspondence to: Bin Hao, email: binhao68@126.com \\ Zubing Mei, email: herrmayor@126.com \\ Keywords: prostate cancer; prognosis; metformin; meta-analysis; survival \\ Received: May 10, $2017 \quad$ Accepted: October 13, $2017 \quad$ Published: October 31, 2017 \\ Copyright: Xiao et al. This is an open-access article distributed under the terms of the Creative Commons Attribution License 3.0 \\ (CC BY 3.0), which permits unrestricted use, distribution, and reproduction in any medium, provided the original author and source \\ are credited.
}

\section{ABSTRACT}

Background: Metformin has been implicated to reduce the risk of prostate cancer (PCa) beyond its glucose-lowering effect. However, the influence of metformin on prognosis of $\mathrm{PCa}$ is often controversial.

Results: A total of 13 cohort studies encompassing 177,490 individuals were included in the meta-analysis. Data on overall survival (OS) and cancer-specific survival (CSS) was extracted from 8 and six studies, respectively. Comparing metformin users with non-metformin users, the pooled hazard ratios (HRs) for OS and CSS were 0.79 (95\% confidence interval [CI] $0.63-0.98$ ) and 0.76 (95\% CI 0.57-1.02), respectively. Subgroup analyses stratified by baseline charcteristics indicated significant CSS benefits were noted in studies conducted in USA/Canada with prospective, large sample size, multiple-centered study design. Five studies reported the PCa prognosis for recurrence-free survival (RFS) and metformin use was significantly associated with patient RFS (HR $0.74,95 \%$ CI, 0.58-0.95).

Methods: Relevant studies were searched and identified using PubMed, Embase and Cochrane databases from inception through January 2017, which investigated associations between the use of metformin and PCa prognosis. Combined HRs with $\mathbf{9 5} \% \mathrm{CI}$ were pooled using a random-effects model. The primary outcomes of interest were os and CSS.

Conclusions: Our findings provide indication that metformin therapy has a trend to improve survival for patients with $\mathrm{PCa}$. Further prospective, multi-centered, large sample size cohort studies are warranted to determine the true relationship.

\section{INTRODUCTION}

Biguanides, commonly known as metformin, are one type of the most widely prescribed drugs mainly to lower blood glucose for patients with type 2 diabetes. Experimental studies have shown that metformin has antineoplastic effects in several malignant tumors, including breast cancer, pancreatic cancer, and prostate cancer (PCa) [1-3].
Metformin has been implicated to restrain mitochondrial complex [1], reducing mitochondrial ATP production, leading to cellular energetic stress [3], which can activate AMPK, resulting in the inhibition of tumor growth through an anti-proliferative phenotype [3, 4]. Metformin can also act as a chemosensitizer. In breast cancer xenograft models, metformin has been shown to enhance the effect of chemotherpy and prolong remission in breast cance cell line. In colon cancer cell lines, metformin 
can enhance the chemosensitivity of 5-fluorouracil and oxaliplatin $[5,6]$. Moreover, metformin has also been shown to improve survival in diabetic patients with advanced endometrial cancer and non-small cell lung cancer [7, 8].

The effect of metformin use in PCa has been examined by many studies [9-22]. Although it has been found in some studies that metformin showed no significant positive association with PCa outcomes $[10,15-17,22]$, while still others reported negative [11, $12,14,18-21]$. Several studies have especially reported that metformin is associated with reduced risk and mortality of PCa [9, 11, 12, 18, 19, 21, 23].

However, these results were controversial. Therefore, we updated the systematic review and meta-analysis to reappraise the prognostic value of metformin in $\mathrm{PCa}$.

\section{RESULTS}

\section{Description of the search and selection of studies}

A total of 561 citations were identified for eligibility through the systematic literature search. After exclusion of duplicate publications and full text review of the relevant studies, A total of 13 cohort studies encompassing 177,490 individuals, with a mean sample size of 13,653 (range 250 to 105,245 ) were included in the quantitative synthesis. Data on overall survival (OS) and cancer-specific survival (CSS) were available from 8 and 6 studies, respectively [10-22] (Figure 1 and Supplementary Tables 1-4).

\section{Study characteristics}

Table 1 provides the baseline characteristics of each study that met our inclusion criteria. All studies were published between 2010 and 2016 in English peerreviewed journals. Five of the included studies were population-based cohort studies and eight were hospitalbased cohort studies. Nine studies has retrospective designs, and four studies has prospective designs. Ten studies were performed in USA or Canada, two in Europe and one in Asia. Five studies involved single-center data, whereas eight were multi-center studies. Assessment of methodological quality by NOS yielded a mean score of 7 (range, 6 to 9), and 8 of 10 studies had a score of 7 or above (Table 2).
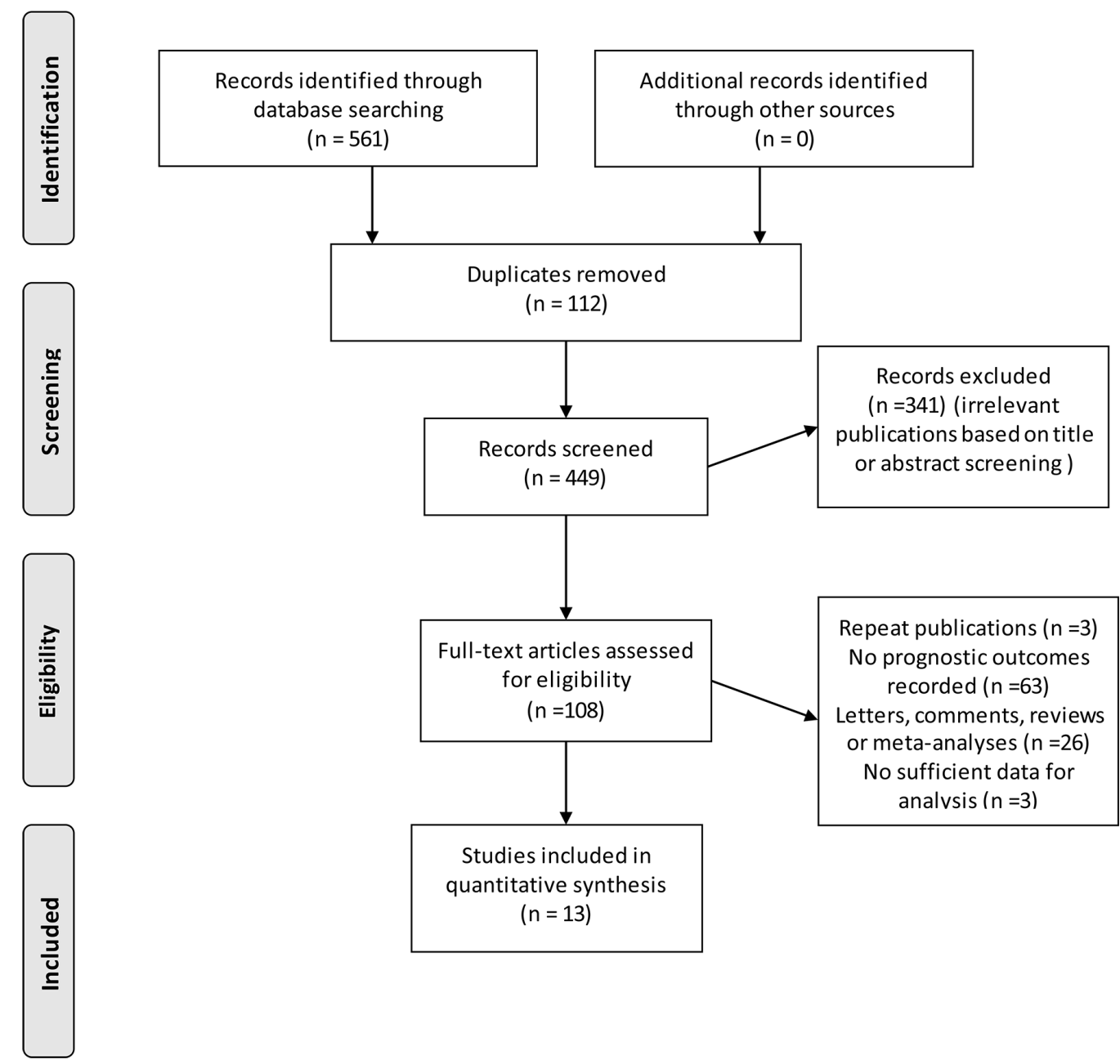

Studies included in quantitative synthesis $(n=13)$

Figure 1: Flow diagram of study selection process investigating effect of metformin use on prostate cancer prognosis. 
Table 1: Baseline characteristics of included studies investigating the survival outcomes of metformin use for PCa patients

\begin{tabular}{|c|c|c|c|c|c|c|c|c|c|c|c|}
\hline $\begin{array}{l}\text { First } \\
\text { author } \\
\text { (year) }\end{array}$ & Country & $\begin{array}{l}\text { Inclusion } \\
\text { period }\end{array}$ & Source of data & $\begin{array}{l}\text { Study } \\
\text { design }\end{array}$ & $\begin{array}{l}\text { Study } \\
\text { setting }\end{array}$ & $\begin{array}{c}\text { No. of } \\
\text { hospitals } \\
\text { involved }\end{array}$ & $\begin{array}{l}\text { Sample } \\
\text { size }\end{array}$ & $\begin{array}{c}\text { Metformin } \\
\text { user/non- } \\
\text { user }\end{array}$ & $\begin{array}{l}\text { Median } \\
\text { follow-up } \\
\text { (years) }\end{array}$ & $\begin{array}{c}\text { Survival } \\
\text { endpoints }\end{array}$ & $\begin{array}{l}\text { Study } \\
\text { quality }\end{array}$ \\
\hline $\begin{array}{l}\text { Mayer } \\
2016\end{array}$ & Canada & $2005-2012$ & $\begin{array}{c}\text { Several Ontario } \\
\text { administrative health } \\
\text { care databases }\end{array}$ & Retrospective & $\begin{array}{l}\text { Population- } \\
\text { based }\end{array}$ & $\begin{array}{l}\text { Multiple } \\
\text { centers }\end{array}$ & 2,832 & $359 / 1,247$ & NR & CSS,OS & 7 \\
\hline $\begin{array}{l}\text { Chong } \\
2016\end{array}$ & USA & NR & $\begin{array}{l}\text { Tumor Registry } \\
\text { at the Memphis } \\
\text { Veterans Affairs } \\
\text { Medical Center }\end{array}$ & Retrospective & $\begin{array}{l}\text { Hospital- } \\
\text { based }\end{array}$ & $\begin{array}{l}\text { Single } \\
\text { center }\end{array}$ & 287 & $138 / 149$ & NR & OS,RFS & 7 \\
\hline $\begin{array}{l}\text { Reznicek } \\
2015\end{array}$ & USA & $2002-2010$ & $\begin{array}{c}\text { Baltimore Veterans } \\
\text { Administration }\end{array}$ & Retrospective & $\begin{array}{l}\text { Hospital- } \\
\text { based }\end{array}$ & $\begin{array}{l}\text { Single } \\
\text { center }\end{array}$ & 1,155 & NR & $5.5(\mathrm{Me})$ & OS & 8 \\
\hline $\begin{array}{l}\text { Randazzo } \\
2015\end{array}$ & Switzerland & $1998-2003$ & ERSPC Aarau & Prospective & $\begin{array}{l}\text { Population- } \\
\text { based }\end{array}$ & $\begin{array}{l}\text { Multiple } \\
\text { centers }\end{array}$ & 10,311 & $150 / 4164$ & 7.6(Me) & OS,CFS & 8 \\
\hline $\begin{array}{l}\text { Lu-Yao } \\
2015\end{array}$ & USA & 2007-2009 & $\begin{array}{l}\text { Surveillance, } \\
\text { Epidemiology, } \\
\text { and End Results- } \\
\text { Medicare linked data }\end{array}$ & Retrospective & $\begin{array}{l}\text { Population- } \\
\text { based }\end{array}$ & $\begin{array}{l}\text { Multiple } \\
\text { centers }\end{array}$ & 22,110 & NR & NR & CSS & 7 \\
\hline $\begin{array}{l}\text { Lee } \\
2015\end{array}$ & Korea & 2006-2013 & $\begin{array}{l}\text { Committee on the } \\
\text { Ethics of the Seoul } \\
\text { National University } \\
\text { Bundang Hospital }\end{array}$ & Retrospective & $\begin{array}{c}\text { Hospital- } \\
\text { based }\end{array}$ & $\begin{array}{l}\text { Single } \\
\text { center }\end{array}$ & 746 & $135 / 74$ & NR & RFS & 8 \\
\hline $\begin{array}{l}\text { Kaushik } \\
2014\end{array}$ & USA & $1997-2010$ & $\begin{array}{c}\text { Mayo Clinic } \\
\text { electronic medical } \\
\text { record }\end{array}$ & Retrospective & $\begin{array}{l}\text { Hospital- } \\
\text { based }\end{array}$ & $\begin{array}{l}\text { Single } \\
\text { center }\end{array}$ & 12,052 & $562 / 323$ & $5.1(\mathrm{Me})$ & $\begin{array}{l}\text { RFS,CFS, } \\
\text { OS }\end{array}$ & 9 \\
\hline $\begin{array}{l}\text { Bensimon } \\
2014\end{array}$ & UK & 1998-2009 & $\begin{array}{l}\text { UK NCDR, the } \\
\text { CPRD, the } \\
\text { HES database, } \\
\text { and the Office for } \\
\text { National Statistics } \\
\text { database }\end{array}$ & Retrospective & $\begin{array}{l}\text { Population- } \\
\text { based }\end{array}$ & $\begin{array}{l}\text { Multiple } \\
\text { centers }\end{array}$ & 15,940 & $242 / 138$ & $3.7(\mathrm{M})$ & CSS,OS & 7 \\
\hline $\begin{array}{l}\text { Spratt } \\
2013\end{array}$ & USA & $1992-2008$ & $\begin{array}{l}\text { Memorial Sloan- } \\
\text { Kettering Cancer } \\
\text { Center }\end{array}$ & Retrospective & $\begin{array}{l}\text { Hospital- } \\
\text { based }\end{array}$ & $\begin{array}{l}\text { Single } \\
\text { center }\end{array}$ & 3,045 & $157 / 162$ & $8.7(\mathrm{Me})$ & CSS & 8 \\
\hline $\begin{array}{l}\text { Margel } \\
2013\end{array}$ & Canada & $1997-2008$ & Several database ${ }^{*}$ & Retrospective & $\begin{array}{c}\text { Population- } \\
\text { based }\end{array}$ & $\begin{array}{l}\text { Multiple } \\
\text { centers }\end{array}$ & 105,245 & $1619 / 2218$ & $4.64(\mathrm{Me})$ & CSS,OS & 8 \\
\hline $\begin{array}{l}\text { Spratt } \\
2012\end{array}$ & USA & 1993-2009 & NR & Retrospective & $\begin{array}{c}\text { Hospital- } \\
\text { based }\end{array}$ & $\begin{array}{l}\text { Single } \\
\text { center }\end{array}$ & 2,901 & $157 / 159$ & $13.4(\mathrm{Me})$ & CSS & 6 \\
\hline $\begin{array}{l}\mathrm{He} \\
2011\end{array}$ & USA & 1999-2008 & $\begin{array}{l}\text { Data from } \\
\text { University of Texas } \\
\text { M. D. Anderson } \\
\text { Cancer } \\
\text { Center }\end{array}$ & Retrospective & $\begin{array}{c}\text { Hospital- } \\
\text { based }\end{array}$ & $\begin{array}{l}\text { Single } \\
\text { center }\end{array}$ & 250 & NR & NR & OS & 6 \\
\hline $\begin{array}{l}\text { Patel } \\
2010\end{array}$ & USA & 1990-2009 & $\begin{array}{c}\text { Columbia University } \\
\text { Urologic Oncology } \\
\text { Database }\end{array}$ & Retrospective & $\begin{array}{c}\text { Hospital- } \\
\text { based }\end{array}$ & $\begin{array}{l}\text { Single } \\
\text { center }\end{array}$ & 616 & $112 / 98$ & NR & RFS & 6 \\
\hline
\end{tabular}

Abbreviations: $\mathrm{BCR}=$ biochemical recurrence; $\mathrm{BMI}=$ body mass index; $\mathrm{CFS}=$ cancer-free survival $\mathrm{CPRD}=\mathrm{Clinical}$ Practice Research Datalink; $\mathrm{CIHI}=\mathrm{Canadian}$ Institute for Health Information; CSS = cancer specific survival; ERSPC = European Randomized Study of Screening for Prostate Cancer; HES = Hospital Episode Statistics; M = mean; $\mathrm{Me}=$ median; $\mathrm{NCDR}=$ National Cancer Data Repository; $\mathrm{NR}=$ not report; $\mathrm{OS}=$ overall survival; $\mathrm{PCa}=$ prostate cancer; $\mathrm{RFS}=$ recurrence-free survival .

"the Ontario Cancer Registry, the Ontario Diabetes Database, the Ontario Health Insurance Plan, the CIHI Discharge Abstract Database, the CIHI National Ambulatory Care Reporting System, the Registered Persons Data Base, the Ontario Drug Benefit database.

\section{Metformin use and PCa survival}

\section{Metformin use and patient overall survival}

As shown in Figure 2A, the pooled hazard ratio (HR) for the OS comparing metformin use versus non-use was 0.79 (95\% CI $0.63-0.98)$, and there was significant interstudy heterogeneity $\left(I^{2}=79.5 \%, P<0.001\right)$. The subgroup analysis limited study region to USA/Canada showed similar result ( $n=6$, HR $0.72,95 \%$ CI $0.57-0.90)$. We also found that studies with retrospective design, sample size less than 10,000 , hospital-based study, single center study, with patients including only diabetics and metformin use calculated as ever versus never use have similar results with the main analysis. However, due to the limited studies included in some subgroups, though the trend of the survival benefits were noted, significant differences were not reached (Table 3A).

\section{Metformin use and patient cancer-specific survival}

Figure 2B showed that the pooled HR for the CSS comparing metformin use versus non-use was 0.76 (95\% CI 0.57-1.02), and there was significant inter-study 
Table 2: Methodological quality of included studies based on the Newcastle-Ottawa Scale for cohort studies

\begin{tabular}{|c|c|c|c|c|c|}
\hline Study & Design & Selection & Comparability & Outcome/exposure & Overall quality $(\max 9)$ \\
\hline Mayer (2016) & Cohort & $* * *$ & ** & ** & 7 \\
\hline Chong (2016) & Cohort & $* * * *$ & ** & $*$ & 7 \\
\hline Reznicek (2015) & Cohort & **** & ** & ${ }^{* *}$ & 8 \\
\hline Randazzo (2015) & Cohort & $* * *$ & ** & $* * *$ & 8 \\
\hline Lu-Yao (2015) & Cohort & ${ }^{* * * *}$ & ** & * & 7 \\
\hline Lee $(2015)$ & Cohort & $* * * *$ & ** & $* * *$ & 9 \\
\hline Kaushik (2014) & Cohort & $* * * *$ & ** & $* * *$ & 9 \\
\hline Bensimon (2014) & Cohort & $* * *$ & ** & ** & 7 \\
\hline Spratt (2013) & Cohort & $* * * *$ & ** & $* *$ & 8 \\
\hline Margel (2013) & Cohort & $* * *$ & ** & $* * *$ & 8 \\
\hline Spratt (2012) & Cohort & $* * *$ & ** & * & 6 \\
\hline $\mathrm{He}(2011)$ & Cohort & $* * *$ & ** & * & 6 \\
\hline Patel (2010) & Cohort & $* * *$ & $* *$ & * & 6 \\
\hline
\end{tabular}

*Study quality assessment of observational studies performed using the Newcastle-Ottawa scale (each asterisk represents if individual criterion within the subsection were fulfilled).

heterogeneity $\left(I^{2}=65.3 \%, P=0.013\right)$. The subgroup analysis limited study region to USA/Canada showed similar result with boundary survival benefit $(n=5$, HR $0.73,95 \% \mathrm{CI}$ $0.53-1.00)$. We also find that studies with prospective design, larger sample size more than 10,000, population-based study and multiple center study have similar trends of survival benefits for metformin use with the main analysis. Due to the limited studies included in the main analysis and some subgroups, through the trend of the survival benefits were found, further large prospective studies need to be conducted to test this association (Table 3B).

Five studies investigated the association between metformin use and recurrence-free survival (RFS), we found that metformin use was significant associated with improved RFS for PCa Patients ( $n=5$, HR $0.74,95 \%$ CI $0.58-0.95)$.

\section{Sensitivity analyses and publication bias}

The tests for funnel plot asymmetry in OS and CSS subset indicated the absence of publication bias, which were further confirmed by Egger's test $(P=0.69$ for OS, $P=0.32$ for CSS $)$, and Begg's test $(P=1.00$ for OS, $P=0.26$ for CSS). The adjusted estimates calculated using the trim-and-fill method were similar with the original analyses for both OS and CSS (Supplementary Table 5). We did not explore the publication bias for RFS due to the limited number of studies involved.

\section{DISCUSSION}

\section{Principal findings of this study}

This present systematic review and meta-analysis represents the most comprehensive review to date on the association between metformin use and PCa prognosis by including 13 cohort studies enrolling 177,490 individuals. Overall, we find that metformin intake has a trend to improve survival for patients with $\mathrm{PCa}$ in terms of OS, CSS and RFS. Significant CSS benefits were noted in studies conducted in USA/Canada with prospective, large sample size, multiple-centered study design.

\section{Comparisons with previous studies}

The result of this study is similar with that of two previous meta-analyses. The first meta-analysis by Stopsack et al [24] found metformin use was associated with improved OS and RFS for patients with PCa by meta-analysing 9 studies. By pooling 8 studies, Hwang et al [25] found that $\mathrm{PCa}$ patients who used metformin had RFS benefits compared with those who did not use metformin. However, due to small number of included studies and limited sample size, no statistical significance was found for other outcomes such as CSS. For the present meta-analysis, we have tried to explore the potential between-study heterogeneity by conducting subgroup analyses in terms of OS subset. Though no significant decrease in heterogeneity of the subgroups, we still could not exclude the potential heterogeneity from these origins. Moreover, the trim-and-fill method further confirmed the robustness of results for OS and CSS. However, it do add the implications that metformin could influence survival in specific individuals with PCa, not in others. We found that metformin use might have overall survival effects in selected patients and well-designed studies, such as in patients involving only diabetics and metformin use calculated as ever versus never use, etc. 
A

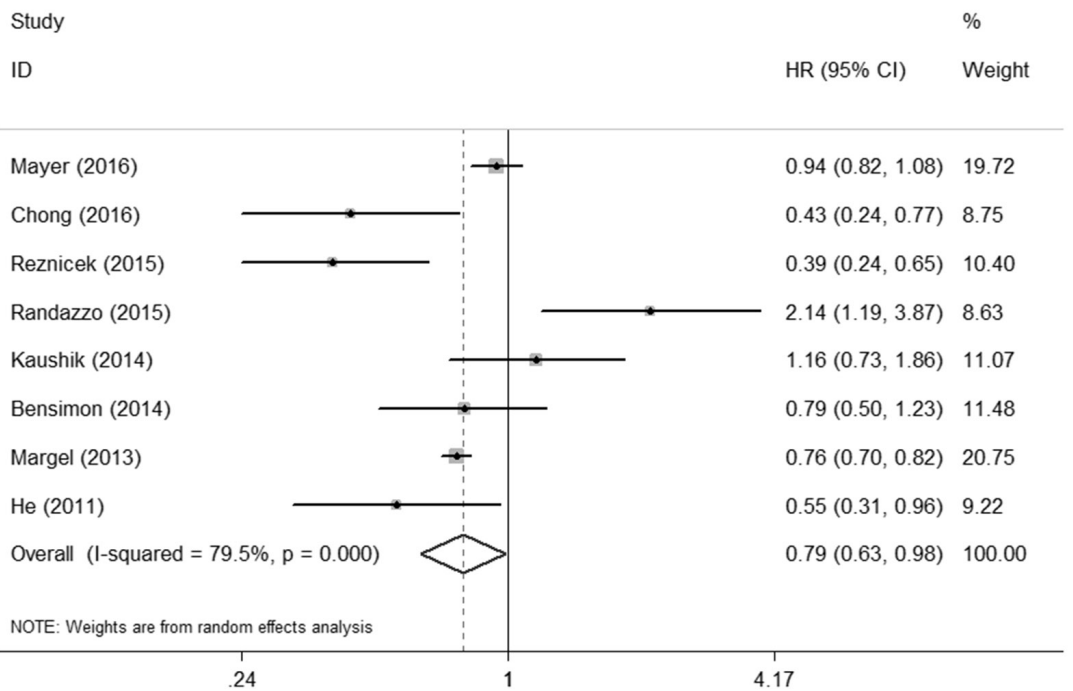

B

Study

ID HR $(95 \% \mathrm{Cl}) \quad$ Weight

\begin{tabular}{lll} 
Mayer (2016) & $0.96(0.79,1.16)$ & 30.82 \\
Lu-Yao (2015) & $0.92(0.54,1.57)$ & 15.97 \\
Bensimon (2014) & $1.09(0.51,2.33)$ & 10.18 \\
Spratt (2013) & $0.19(0.06,0.65)$ & 4.98 \\
Margel (2013) & $0.76(0.64,0.89)$ & 31.98 \\
Spratt (2012) & $0.26(0.09,0.75)$ & 6.07 \\
Overall (I-squared = 65.3\%, p=0.013) & $0.76(0.57,1.02)$ & 100.00 \\
NOTE: Weights are from random effects analysis & & \\
\hline 1 & 1 & 16.7
\end{tabular}

C Study

ID

$\%$

$\mathrm{HR}(95 \% \mathrm{Cl}) \quad$ Weight

Chong (2016)

Kaushik (2014)

Spratt (2012)

Patel (2010)

Lee (2012)

Overall (I-squared $=29.0 \%, p=0.228$ )

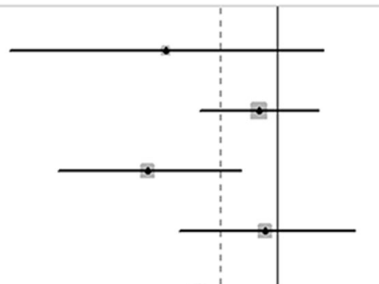

$0.56(0.25,1.27) \quad 8.37$

$0.91(0.67,1.24) \quad 33.92$

$0.51(0.32,0.83) \quad 19.79$

$0.94(0.60,1.50) \quad 20.92$

$0.66(0.39,1.12) \quad 17.00$

$0.74(0.58,0.95) \quad 100.00$

NOTE: Weights are from random effects analysis

.25

Figure 2: Funnel plot of studies investigating association between metformin use and (A) overall survival, (B) cancer-specific survival, (C) recurrence-free survival. 
Table 3A: Subgroup analysis of overall survival

\begin{tabular}{|c|c|c|c|c|c|}
\hline & HR & $95 \% \mathrm{CI}$ & $\begin{array}{l}\text { Degree of heterogeneity } \\
\left(I^{2} \text { statistics; \% }\right)\end{array}$ & $P$-value & $\begin{array}{l}\text { No. of included } \\
\text { Studies }\end{array}$ \\
\hline \multicolumn{6}{|l|}{ Study quality } \\
\hline Score $\geq 8$ & 0.9 & 0.54 to 1.50 & 86.2 & $<0.001$ & 4 \\
\hline Score $<8$ & 0.7 & 0.49 to 1.00 & 68.8 & 0.022 & 4 \\
\hline \multicolumn{6}{|l|}{ Study region } \\
\hline USA/Canada & 0.72 & 0.57 to 0.90 & 78.4 & $<0.001$ & 6 \\
\hline Europe & 1.28 & 0.48 to 3.38 & 85.6 & 0.008 & 2 \\
\hline \multicolumn{6}{|l|}{ Study design } \\
\hline Prospective & 2.14 & 1.19 to 3.87 & - & - & 1 \\
\hline Retrospective & 0.73 & 0.59 to 0.89 & 74.1 & 0.001 & 7 \\
\hline \multicolumn{6}{|l|}{ Sample size } \\
\hline$<10000$ & 0.56 & 0.33 to 0.95 & 84.2 & $<0.001$ & 4 \\
\hline$\geq 10000$ & 1.04 & 0.69 to 1.55 & 79.2 & 0.002 & 4 \\
\hline \multicolumn{6}{|l|}{ Study setting } \\
\hline Hospital-based & 0.58 & 0.34 to 0.97 & 74.7 & 0.008 & 4 \\
\hline Population-based & 0.93 & 0.73 to 1.19 & 82.8 & 0.001 & 4 \\
\hline \multicolumn{6}{|l|}{ Number of hospital } \\
\hline Single & 0.58 & 0.34 to 0.97 & 74.7 & 0.008 & 4 \\
\hline Multiple & 0.93 & 0.73 to 1.19 & 82.8 & 0.001 & 4 \\
\hline \multicolumn{6}{|l|}{ Diabetics only } \\
\hline Yes & 0.66 & 0.50 to 0.87 & 66.2 & 0.011 & 6 \\
\hline No & 1.35 & 0.61 to 3.00 & 85.9 & 0.008 & 2 \\
\hline \multicolumn{6}{|l|}{ Effect estimates } \\
\hline Time varing HR & 0.84 & 0.65 to 1.08 & 83.2 & $<0.001$ & 6 \\
\hline Not HR & 0.6 & 0.33 to 1.09 & 61.8 & 0.105 & 2 \\
\hline \multicolumn{6}{|l|}{ Metformin use } \\
\hline Cumulative use & 0.78 & 0.51 to 1.19 & 83.2 & $<0.001$ & 6 \\
\hline Ever vs never use & 0.76 & 0.70 to 0.82 & 0 & 0.868 & 2 \\
\hline \multicolumn{6}{|l|}{ Statistical method } \\
\hline Time varying cox regression & 0.82 & 0.54 to 1.25 & 82.7 & $<0.001$ & 5 \\
\hline Single regression & 0.74 & 0.49 to 1.11 & 70.8 & 0.032 & 3 \\
\hline
\end{tabular}

This really gives implications in future design of clinical interventional study.

\section{Potential mechanisms}

Several potential mechanisms for the antineoplastic action of metformin have been noted. Metformin, as an activator of AMP-activated protein kinase (AMPK), may play an important role in cancer metabolism. AMPK pathway is reported to inhibit mTOR signaling and result in fatty acid synthesis, inhibition of protein synthesis, and cell proliferation [26]. It has been reported that fatty acid synthase is overexpressed in $\mathrm{PCa}$, breast cancer and pancreatic cancer, which is necessary for de novo fatty acid biosynthesis and malignant phenotype. AMPK activation can reduce the expression of fatty acid synthase and acetyl-CoA carboxylase, which diminishes the metabolization and growth of PCa cells [27]. Zadra et al [28] also suggested that suppression of de novo lipogenesis affected AMPK-mediated inhibition of PCa growth. In addition, metformin plays a role in cyclin-dependent kinase (CDK) induction of autophagy, cell cycle arrest, and apoptosis. Metformin can reduce the activity of cyclin D1, leading to the inhibition of PCa cell lines [29]. It has been vertified that the cyclin D1 pathway can serve as a regulator of androgendependent transcription and cell cycle progression in PCa cells [30]. 


\begin{tabular}{|c|c|c|c|c|c|}
\hline & HR & $95 \%$ CI & $\begin{array}{c}\text { Degree of heterogeneity } \\
\left(I^{2} \text { statistics; \% }\right)\end{array}$ & $P$-value & $\begin{array}{c}\text { No. of included } \\
\text { Studies } \\
\end{array}$ \\
\hline \multicolumn{6}{|l|}{ Study quality } \\
\hline Score $\geq 8$ & 0.43 & 0.11 to 1.64 & 80.4 & 0.024 & 2 \\
\hline Score $<8$ & 0.85 & 0.58 to 1.24 & 48.5 & 0.12 & 4 \\
\hline \multicolumn{6}{|l|}{ Study region } \\
\hline USA/Canada & 0.73 & 0.53 to 1.00 & 71.2 & 0.008 & 5 \\
\hline Europe & 1.09 & 0.51 to 2.33 & & $<0.001$ & 1 \\
\hline \multicolumn{6}{|l|}{ Study design } \\
\hline Prospective & - & - & - & - & 0 \\
\hline Retrospective & 0.76 & 0.57 to 1.02 & 65.3 & 0.013 & 6 \\
\hline \multicolumn{6}{|l|}{ Sample size } \\
\hline$<10000$ & 0.4 & 0.13 to 1.3 & 83.6 & 0.002 & 3 \\
\hline$\geq 10000$ & 0.78 & 0.67 to 0.91 & 0 & 0.548 & 3 \\
\hline \multicolumn{6}{|l|}{ Study setting } \\
\hline Hospital-based & 0.23 & 0.10 to 0.50 & 0 & 0.7 & 2 \\
\hline Population-based & 0.86 & 0.74 to 1.00 & 21.2 & 0.283 & 4 \\
\hline \multicolumn{6}{|l|}{ Number of hospital } \\
\hline Single & 0.86 & 0.74 to 1.00 & 21.2 & 0.283 & 4 \\
\hline Multiple & 0.23 & 0.10 to 0.50 & 0 & 0.7 & 2 \\
\hline
\end{tabular}

\section{Strengths and limitations of the study}

There were several limitations in our study. First, the statistical analysis of publication bias was insufficiently powered due to the small number of included studies for OS $(n=8)$ and CSS $(n=6)$ subsets, although the results were adjusted by the trim-and-fill model. Secondly, the sensitivity analyses could not be carried out related to the tumor site, disease stage and follow-up period because of unavailability of these data from the included studies, and these factors can also affect the prognosis of PCa patients. Thirdly, the accuracy and precision of the summary estimates could be influenced by the different survival analysis approaches. Although most of the studies used multivariate Cox proportional hazards model, other studies did not report the statistical models [17, 20], while another study did not utilize multivariate analysis [11]. In addition, adjustment variables between the included studies are not completely consistent. Fourthly, we were not able to contact the authors or sponsors of some studies to retrieve the data which were excluded from our analyses $[12,20]$. This might lead to publication bias for pooled estimates.

Several important strengths of our study are presented as follows. Firstly, we performed a comprehensive search of the relevant studies in several main databases without language, publication date or publication type (both full text and abstract) limits, enabling us to select the maximal number of suitable studies for analysis. Secondly, the large sample size including over 100,000 individuals enabled us to quantitatively assess the association between metformin use and PCa prognosis, making it the most powerful and comprehensive synthesis of the evidence on this issue to date. Thirdly, we performed appropriate subgroup analyses for some key study characteristics, such as the study design, study setting, and Newcastle-Ottawa scale (NOS) scale for study quality. Fourthly, we selected and cross-checked the identified studies, developed the data abstraction forms, abstracted the data and assessed the study quality at least by two independent authors to avoid subjectivity to the greatest extent, making the process of the systematic review more objectively.

In summary, our current systematic review and metaanalysis found that metformin was beneficial for survival in patients with $\mathrm{PCa}$, although the true association still need further confirmation based on the existing evidence. Nevertheless, this report indeed provides a direction for clinicians in the treatment of PCa. In future, larger prospective cohort studies, or even randomized controlled trials with longer follow-up period are needed to confirm the associations between metformin intake and PCa survival.

\section{MATERIALS AND METHODS}

\section{Literature search}

A search strategy in line with the preferred reporting items for systematic reviews and meta-analysis (PRISMA) statement was developed [31]. We performed systematic 
literature searches of PubMed, Embase and Cochrane databases from inception through January 2017 which investigated associations between metformin use and $\mathrm{PCa}$ prognosis. Supplementary Tables 1-3 present the above three database search strategies by using the combinations of following terms: 'metformin', 'biguanides', 'prostate', 'prostatic', 'cancer', 'carcinoma', 'mortality', 'prognosis', 'prognostic' and 'survival'. We also performed manual reference search of the reference lists from the initial identified relevant studies, reviews and meta-analysis. We restricted the publication language only to English language studies, given the fact that studies published in other languages were often not available for both authors and readers.

\section{Study selection}

Two authors (Liu and Chu) independently assessed the searched all the citations through the primary literature search, then identified the final relevant studies for eligibility. Agreement was reached for the discrepancies through discussion or by a senior author (Hao or $\mathrm{Xu}$ ) if necessary. Studies were considered eligible for inclusion if the following criteria were met: prospective or retrospective cohort studies reported prognostic effects in PCa patients comparing metormin users with non-users, and survival estimates $\mathrm{HRs}$ / risk ratios (RRs) with 95\% CIs could be abstracted or calculated using the method reported by Parmar [32]. We used the most detailed or recent information for publications with overlapped data.

\section{Data extraction}

The characteristics of each study included were extracted including the first author, publication year, study region and design, study setting, hospital number involved, sample size, follow-up duration, survival endpoints, and HRs or RRs with corresponding 95\% CIs and adjusted variables.

\section{Quality assessment}

Methodological quality assessment for each study included was performed by two authors (Liu and Chu) and was scored them using the NOS [33]. The two authors scored the study quality of reviewed studies independently, and reach a consensus value for each item.

\section{Statistical analysis}

All analyses were performed by using STATA 12.0 (StataCorp LP, College Station, TX). Survival estimates (HRs/RRs with 95\% CIs) with full adjustments were abstracted from the included studies and pooled using random-effects model [34]. An observed HR $<1$ implied an improved survival for the group with metformin use. The HRs for the study endpoints of OS, CSS and RFS were pooled separately. Between-study heterogeneity was assessed using $I^{2}$ statistic and the Cochrane Q statistic, defined as an $I^{2}$-value $>50 \%$ and $p$-value $<0.10$ indicating substantial heterogeneity, respectively [35].

To further explore the potential heterogeneity, we performed subgroup analyses by investigating potential influencial variables that could explain some of the heterogeneity. Subgroup differences were calculated using the methods described by Deeks et al [36].

Publication bias was assessed by visual inspection of a funnel plot symmetry and using methods reported by Egger et al and Begg et al [37, 38]. We also examined the potential effect of publication bias through Duval's nonparametric trim-and-fill method [39] to adjust the pooled HR.

\section{CONFLICTS OF INTEREST}

The authors declare no competing financial interests.

\section{GRANT SUPPORT}

This work was supported by Medical Key Scientific and Technological Project of Henan Province (grant no. 201701013), Key Scientific and Technological Project of Henan Provincial Department of Science and Technology (grant no. 172102310577) and the National Natural Science Foundation of China (grant no. 81774112).

\section{REFERENCES}

1. DeCensi A, Puntoni M, Gandini S, Guerrieri-Gonzaga A, Johansson HA, Cazzaniga M, Pruneri G, Serrano D, Schwab M, Hofmann U, Mora S, Aristarco V, Macis D, et al. Differential effects of metformin on breast cancer proliferation according to markers of insulin resistance and tumor subtype in a randomized presurgical trial. Breast Cancer Res Treat. 2014; 148:81-90.

2. Sadeghi N, Abbruzzese JL, Yeung SC, Hassan M, Li D. Metformin use is associated with better survival of diabetic patients with pancreatic cancer. Clin Cancer Res. 2012; 18:2905-12.

3. Pollak M. The insulin and insulin-like growth factor receptor family in neoplasia: an update. Nat Rev Cancer. 2012; 12:159-69.

4. Mayer MJ, Klotz LH, Venkateswaran V. Metformin and prostate cancer stem cells: a novel therapeutic target. Prostate Cancer Prostatic Dis. 2015; 18:303-9.

5. Zhang Y, Guan M, Zheng Z, Zhang Q, Gao F, Xue Y. Effects of metformin on CD133+ colorectal cancer cells in diabetic patients. PloS One. 2013; 8:e81264. 
6. Nangia-Makker P, Yu Y, Vasudevan A, Farhana L, Rajendra SG, Levi E, Majumdar AP. Metformin: a potential therapeutic agent for recurrent colon cancer. PloS One. 2014;9:e84369.

7. Ezewuiro O, Grushko TA, Kocherginsky M, Habis M, Hurteau JA, Mills KA, Hunn J, Olopade OI, Fleming GF, Romero IL. Association of Metformin Use with Outcomes in Advanced Endometrial Cancer Treated with Chemotherapy. PloS One. 2016;11:e0147145.

8. Tan BX, Yao WX, Ge J, Peng XC, Du XB, Zhang R, Yao B, Xie K, Li LH, Dong H, Gao F, Zhao F, Hou JM, et al. Prognostic influence of metformin as first-line chemotherapy for advanced nonsmall cell lung cancer in patients with type 2 diabetes. Cancer. 2011; 117:5103-11.

9. Wright JL, Stanford JL. Metformin use and prostate cancer in Caucasian men: results from a population-based casecontrol study. Cancer Causes Control. 2009; 20:1617-22.

10. Mayer MJ, Klotz LH, Venkateswaran V. The effect of metformin use during docetaxel chemotherapy on prostate cancer-specific and overall survival of diabetic castration-resistant prostate cancer patients. J Urol. 2017; 197:1068-75.

11. Chong RW, Vasudevan V, Zuber J, Solomon SS. Metformin Has a Positive Therapeutic Effect on Prostate Cancer in Patients With Type 2 Diabetes Mellitus. Am J Med Sci. 2016; 351:416-9.

12. Reznicek D, Klyushnenkova E, Alexander R. Metformin use predicts an overall survival advantage in diabetic veterans with prostate cancer. J Urol. 2015; 193:e146-e7.

13. Randazzo M, Beatrice J, Huber A, Grobholz R, Manka L, Wyler SF, Chun FF, Recker F, Kwiatkowski M. Influence of metformin use on PSA values, free-to-total PSA, prostate cancer incidence and grade and overall survival in a prospective screening trial (ERSPC Aarau). World J Urol. 2015; 33:1189-96.

14. Lu-Yao GL, Lin Y, Moore D, Graff J, Stroup A, McGuigan K, Crystal S, Amin S, Demissie K, DiPaola RS. Combination statin/metformin and prostate cancer specific mortality: A population-based study. J Clin Oncol. 2015; 33.

15. Lee H, Kuk H, Byun SS, Lee SE, Hong SK. Preoperative glycemic control status as a significant predictor of biochemical recurrence in prostate cancer patients after radical prostatectomy. PloS One. 2015;10:e0124761.

16. Kaushik D, Karnes RJ, Eisenberg MS, Rangel LJ, Carlson RE, Bergstralh EJ. Effect of metformin on prostate cancer outcomes after radical prostatectomy. Urol Oncol. 2014; 32:43.e1-7.

17. Bensimon L, Yin H, Suissa S, Pollak MN, Azoulay L. The use of metformin in patients with prostate cancer and the risk of death. Cancer Epidemiol Biomarkers Prev. 2014; 23:2111-8.

18. Spratt DE, Zhang C, Zumsteg ZS, Pei X, Zhang Z, Zelefsky MJ. Metformin and prostate cancer: reduced development of castration-resistant disease and prostate cancer mortality. Eur Urol. 2013; 63:709-16.
19. Margel D, Urbach DR, Lipscombe LL, Bell CM, Kulkarni G, Austin PC, Fleshner N. Metformin use and all-cause and prostate cancer-specific mortality among men with diabetes. J Clin Oncol. 2013; 31:3069-75.

20. Spratt D, Zhang C, Zumsteg ZS, Pei X, Zhang Z, Yamada J, Kollmeier M, Cox B, Zelefsky MJ. Metformin improves prostate cancer-specific survival and inhibits the development of castrate resistant metastasis. Int J Radiat Oncol Biol Phys. 2012; 84:S93.

21. He XX, Tu SM, Lee MH, Yeung SC. Thiazolidinediones and metformin associated with improved survival of diabetic prostate cancer patients. Ann Oncol. 2011; 22:2640-5.

22. Patel T, Hruby G, Abate-Shen C, Badani K, McKiernan J. The impact of diabetes and metformin use in clinically localized prostate cancer treated by radical prostatectomy. $\mathrm{J}$ Urol. 2010;183:e102.

23. Zhang F, Yang Y, Skrip L, Hu D, Wang Y, Wong C, Qiu J, Lei H. Diabetes mellitus and risk of prostate cancer: an updated meta-analysis based on 12 case-control and 25 cohort studies. Acta Diabetol. 2012; 49:S235-46.

24. Stopsack KH, Ziehr DR, Rider JR, Giovannucci EL. Metformin and prostate cancer mortality: a meta-analysis. Cancer Causes Control. 2016; 27:105-13.

25. Hwang IC, Park SM, Shin D, Ahn HY, Rieken M, Shariat SF. Metformin association with lower prostate cancer recurrence in type 2 diabetes: a systematic review and meta-analysis. Asian Pac J Cancer Prev. 2015; 16:595-600.

26. Dowling RJ, Zakikhani M, Fantus IG, Pollak M, Sonenberg N. Metformin inhibits mammalian target of rapamycin-dependent translation initiation in breast cancer cells. Cancer Res. 2007; 67:10804-12.

27. Xiang X, Saha AK, Wen R, Ruderman NB, Luo Z. AMPactivated protein kinase activators can inhibit the growth of prostate cancer cells by multiple mechanisms. Biochem Biophys Res Commun. 2004; 321:161-7.

28. Zadra G, Photopoulos C, Tyekucheva S, Heidari P, Weng QP, Fedele G, Liu H, Scaglia N, Priolo C, Sicinska E, Mahmood U, Signoretti S, Birnberg N, et al. A novel direct activator of AMPK inhibits prostate cancer growth by blocking lipogenesis. EMBO Mol Med. 2014; 6:519-38.

29. Ben Sahra I, Laurent K, Loubat A, Giorgetti-Peraldi S, Colosetti P, Auberger P, Tanti JF, Le Marchand-Brustel Y, Bost F. The antidiabetic drug metformin exerts an antitumoral effect in vitro and in vivo through a decrease of cyclin D1 level. Oncogene. 2008; 27:3576-86.

30. Comstock CE, Revelo MP, Buncher CR, Knudsen KE. Impact of differential cyclin D1 expression and localisation in prostate cancer. Br J Cancer. 2007; 96:970-9.

31. Moher D, Liberati A, Tetzlaff J, Altman DG, and PRISMA Group. Preferred reporting items for systematic reviews and meta-analyses: the PRISMA statement. Int J Surg. 2010; 8:336-41. 
32. Parmar MK, Torri V, Stewart L. Extracting summary statistics to perform meta-analyses of the published literature for survival endpoints. Stat Med. 1998; 17:2815-34.

33. Stang A. Critical evaluation of the Newcastle-Ottawa scale for the assessment of the quality of nonrandomized studies in meta-analyses. Eur J Epidemiol. 2010; 25:603-5.

34. Van Houwelingen HC, Arends LR, Stijnen T. Advanced methods in meta-analysis: multivariate approach and metaregression. Stat Med. 2002; 21:589-624.

35. Higgins JP, Thompson SG. Quantifying heterogeneity in a meta-analysis. Stat Med. 2002; 21:1539-58.

36. Deeks JJ, Altman DG, Bradburn MJ. Statistical Methods for Examining Heterogeneity and Combining Results from Several
Studies in Meta-Analysis. BMJ Publishing Group. 2008; 2:285-312. http://dx.doi.org/10.1002/9780470693926.ch15.

37. Begg CB, Mazumdar M. Operating characteristics of a rank correlation test for publication bias. Biometrics. 1994; 50:1088-101.

38. Egger M, Smith GD, Schneider M, Minder C. Bias in metaanalysis detected by a simple, graphical test. BMJ. 1997; 315:629-34.

39. Duval S, Tweedie R. Trim and fill: A simple funnel-plotbased method of testing and adjusting for publication bias in meta-analysis. Biometrics. 2000; 56:455-63. 